\title{
A Brief Biography of Pierre Alfred Laurent: A Distinguished Chemist from the Instituto Superior Técnico
}

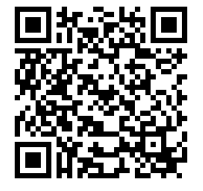

\author{
Paulo Nuno Martins* \\ Interuniversity Center for History of Science and Technology, CIUHCT, Campus of Caparica, Caparica, Portugal
}

Submission: July 25, 2019; Published: August 09, 2019

"Corresponding author: Paulo Nuno Martins, Interuniversity Center for History of Science and Technology, CIUHCT, Campus of Caparica, Building VII, Floor 2,2829-516 Caparica, Portugal

\begin{abstract}
Pierre Alfred Laurent was a distinguished French chemist of the second half of the XX century. In this short communication, I will describe the most important topics of his life, especially in the area of chemistry.

Keywords: Scholar and researcher of organic chemistry at Instituto Superior Técnico; Director of the Portuguese Institute of Industrial Research; Pedagogical perspective on the learning of organic chemistry both in university and industry; Organic chemistry laboratory at Instituto Superior Técnico
\end{abstract}

\section{Introduction}

Pierre Alfred Laurent was born in Saint-Louis (Upper-Rhine) in 1909 in France. It is known that he was an important chemist in the first half of the twentieth century. Thus, in the early 1950s, through an invitation made by the Portuguese Government, Pierre Laurent came to Lisbon in order to teach all subjects about organic chemistry to students of chemical Engineering course at Instituto Superior Técnico (the largest engineering school in Portugal) [1].

In fact, this distinguished Professor of chemistry replaced Peres de Carvalho who had been removed in 1947 from the academic staff for "political reasons." In this sense, Professor Pierre Laurent outlined the manuals of the programs of organic chemistry at Instituto Superior Técnico, which was followed by this school of Portuguese Engineering until 1961.

In addition to the positions associated with teaching and investigation, Pierre Laurent also took part on other positions that were important for the development of Portuguese industrial chemistry, such as the director of the National Institute of Industrial Research (group of Chemical and Biological Laboratories). In Portugal, he also participated in several congresses, namely at the XV International Congress of Pure and Applied Chemistry (IUPAC), together with D. António Pereira
Forjaz, which took place between 9th and 16th September 1956, in Lisbon. It should be noted that the precise date and place of death of Professor Pierre Laurent is unknown.

\section{Methods}

In this short communication on Pierre Alfred Laurent, I chose the 10 main scientific sources (based in the "impact factor") that are available in university libraries and public research institutions in order to give the reader a succinct but rigorous idea on this subject.

\section{Results and Discussion}

In this section, I will refer the most important results of my investigation about the Pierre Laurent's works on chemistry. In this regard, Pierre Laurent has devoted himself to research and teaching within the field of organic chemistry, particularly in the field of 'essential oils' [2], such as eucalyptus oil that led to the publication of numerous works together with some of his students. An example of this collaboration was the case with his student named by Frausto da Silva (who would later become an eminent Portuguese chemist, and Minister of Education of Portugal). Furthermore, Professor Pierre Laurent sought in his work an intense exchange between the university environment 
and industry, as well as a contact with high quality international and national entities in the area of organic chemistry.

In 1954, regarding his pedagogical perspective on the learning of organic chemistry between university and industry, Pierre Laurent argued in one of his conferences (attended by the Representative of Embassy of France) entitled "Some Potential Aspects of Portuguese Industry" that organic chemistry should be learned both in academic environment (where the theoretical teaching of organic chemistry should have a privileged place) and in industry (where practical knowledge and economic sensitivity would be acquired by the engineer) [3].

In fact, Professor Pierre Laurent advocated universityindustry cooperation, suggesting that industrial managers should contribute financially to the scientific and technological development of this area of knowledge, as already occurred in other European countries, because this procedure could be beneficial for both entities: engineers could gain practical experience, while industrial managers could obtain chemicals products with higher quality [4].

At the same conference, Pierre Laurent also referred to the quality of the various raw materials in Portugal, which could be economically advantageous for the Portuguese chemical industry, such as stearic acid (which could be obtained from the fat of various Portuguese raw materials), oleic acid (which could be obtained from olive oil), glutamic acid (which could be obtained from carob seed). In 1961, the glutamic acid was the basis of a research work carried out between Professor Pierre Laurent and Engineer Carlos Beaumont (from Petrochemical) and Engineer Rui Castelhano (from Soda Póvoa), where it was shown that obtaining glutamic acid from carob seed was both scientific and economically viable for Portugal through the exportation of this product to the United States [5].

On the other hand, regarding the practical collaboration with international entities, I would like to highlight those carried out with the German chemical industry BASF, through the Research Laboratory manager, Dr. Walter Reppe, as well as those of an academic nature, namely with the University of Liège, through the Laboratory manager, Dr. Pierre Tarte. For example, the academic work carried out jointly by Professor Pierre Laurent and Professor Tarte on "the synthesis of macrocyclic acetates: 1,3,6 - trioxane and 1,3 - dioxane", it was carried out both at the Instituto Superior Técnico and at the Laboratory of the University of Liège, which was an example of this dynamism of international collaboration [6].

In relation to the practical collaboration with national entities, I would like to highlight the support from the Calouste Gulbenkian Foundation and the Portuguese Institute of High Culture, as well as some Portuguese chemical companies, which unequivocally contributed to the construction of the "new" organic chemistry Laboratory, in the Instituto Superior Técnico, under the guidance of Professor Pierre Laurent. In fact, the chemical Engineering course at Instituto Superior Técnico required both a strong theoretical and a practical component that led Professor Pierre Laurent to the improvement of organic chemistry laboratory of this prestigious Portuguese Engineering school, in the 1950s and 1960s [7].

So, in 1953-1954, I must mention the support of several entities that allowed a "new" organic chemistry laboratory to be built in this Portuguese engineer school. It was built with exclusive "products of national origin" - as argued by Professor Pierre Laurent - such as Portuguese Dyrup, Ciba, the Portuguese Liquid Air Society, among other companies. In this regard, Professor Pierre Laurent has established several contacts in order to quickly conclude this project in Portugal, namely with the collaboration of Engineer Frederico Ulrich, former Minister of Public Works and Director of the Atomic Energy Center, as well as with Engineer Saraiva and Sousa, under-Secretary of Portuguese State for Public Works, who "accelerated the formalities of this work", as Pierre Laurent said publicly.

Thus, since then, a number of practical works in organic chemistry have been done in this laboratory, such as one carried out with Maria Inês Soares, which was published in the prestigious «Portuguese Journal of Chemistry» on "the infrared spectra of oxazolidines (oxazolidines in position 2 and n)" [8]. In this research work, it was studied the issue of "symmetry" in organic chemistry, referring to by Professor Pierre Laurent that «the band that appears in the infrared spectra corresponds to the respiration vibration of the oxazolidine nucleus because due to the asymmetry of the molecule, such vibration is active in infrared. In cyclopentane, the same vibration is inactive at infrared, presenting in Raman a frequency of 890/930 cm-1».

Finally, Pierre Laurent, an eminent French chemist who motivated several young engineers from Instituto Superior Técnico for research, education and industry, was removed from the academic staff of this Institution for political reasons during the Salazar government (perhaps for keeping in touch with Russian scientists), in the 1960s [9]. Thus, Professor Pierre Laurent went to Tanarive College, in Madagascar, but without continuing disciples of his work at the Instituto Superior Técnico, in Portugal.

\section{Conclusion}

In summary, Professor Pierre Laurent was arguably a reference in teaching, pedagogy and investigation in the field of organic chemistry for Portuguese engineers of the Instituto Superior Técnico, in the 1950s and 1960s [10].

\section{References}

1. Archives of Instituto Superior Técnico (2012) Biographical Notes of Pierre Alfred Laurent, Lisbon, Portugal.

2. Pierre Laurent, Elvira Arsénio, Marie Aurore Presa (1957) Raffinage de l'essence d'Eucalyptus, Revista Técnica, Portugal.

3. Pierre Laurent (1954) Quelques Aspects Potentiels de L'Industrie Portugaise vus par um Etranger, Revista Técnica, Portugal. 
4. Pierre Laurent (1955) L'Industrie, la recherche scientifique et l'ingénieur, Revista Técnica, Portugal.

5. Pierre Laurent, Carlos Beaumont, Rui Castelhano (1961) Obtention de l'acide glutamique a partir du germe de caroubier, Revista Técnica, Portugal.

6. Pierre Laurent, Pierre Tarte (1959) Acetals Macrocycliques: 1,3,6-Trioxocane et 1,3-Dioxepane, Revista Portuguesa de Química, Portugal.

7. Paulo Martins (2017) Organic chemistry in Portugal from 1900 to 1970: A contribution to the History of Science. Orbital: Electronic Journal of Chemistry 9(5):363-371.
8. Pierre Laurent, Maria Inês Valente Soares (1964) Espectros Infravermelhos de Oxazolidinas, Oxazolidinas 2 e $\mathrm{N}$ derivadas, Revista Portuguesa de Química, Portugal.

9. Archives of Torre do Tombo (2012) Biographical Notes of Pierre Alfred Laurent, Lisbon, Portugal.

10. Pierre Laurent, J Antunes Gomes (1954) Contribution à l'étude des systèmes ternaires de démixtion en milieu aquo-organique. Les systèmes $\mathrm{CO}_{3} \mathrm{~K}_{2}, \mathrm{H}_{2} \mathrm{O}$, solvant organique, Revista Técnica, Portugal.

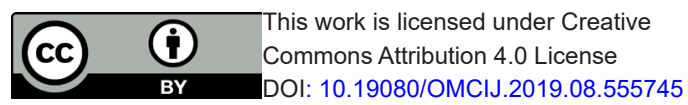

